\title{
VARIATIONS IN CLEANING BETWEEN THE SEXES OF SINELLA COECA (COLLEMBOLA: ENTOMOBRYIDAE)*
}

\author{
By Elizabeth S. Waldorf \\ Department of Zoology \\ Louisiana State University \\ Baton Rouge, Louisiana 70803
}

With the widespread and frequent occurrence of pheromones among insects, it is easy to appreciate the significance of cleaning and grooming behaviors. However these behaviors are as yet poorly known. Among springtails two papers by Simon (1961, 1963) present the most thorough reports. These describe the types of cleaning in representatives of several families, noting the widespread, though infrequent, use of cleaning droplets released from the mouth.

My work examines Sinella coeca (Schott) (Family Entomobryidae) for behavioral differences between the sexes. In particular, I have determined the frequency of cleaning and the duration of bouts of cleaning behavior. The initial expectation is that the sexes will spend about equal time cleaning. However, since males are more active, moving about most of the time, their bouts of cleaning are probably shorter. To compensate, I expected males to have more frequent cleaning sessions. An experiment was carried out to test these expectations.

\section{Methons}

Sinella coeca was reared in mass culture as described previously for Sinella curviseta (Waldorf, I97 I). Cultures were maintained at room temperature $\left(23^{\circ} \pm \mathrm{I}^{\circ} \mathrm{C}\right)$ and supplied commercial yeast as food. Males and females were isolated in individual glass vials with plastic caps. The vials, measuring $18.1 \mathrm{~mm}$ in inner diameter, contained a moist plaster of paris-charcoal substrate (to maintain high humidity) and food. After 24-26 hours of isolation, each animal was observed for five minutes, and the number of bouts of cleaning and the total time (out of 5 minutes) engaged in cleaning recorded. This procedure was followed for 50 males and 50 females. To prevent bias the vials were mixed so that during the observation periods the sex of test animals was usually unknown.

*Manuscript received by the editor May 20, 1974. 
Table 1. Characteristics of male and female bouts of cleaning behavior.

\begin{tabular}{|c|c|c|c|c|c|c|}
\hline & & $\begin{array}{l}\text { aber } \\
\text { /an }\end{array}$ & & & $\begin{array}{l}\text { ngtl } \\
\text { (i }\end{array}$ & \\
\hline & $\bar{x}$ & $\mathrm{n}$ & SD & $\overline{\mathbf{x}}$ & $\mathrm{n}$ & SD \\
\hline Males & 1.88 & 50 & 1.33 & 29.4 & 94 & 38.6 \\
\hline Females & 1.38 & 50 & 1.23 & 23.8 & 69 & 29.5 \\
\hline
\end{tabular}

\section{RESULTS}

The data in Table I present the overall characteristics of males and females. Comparison of the lengths of bouts using a t-test shows that these are not significantly different $(t=\mathrm{I} .049)$. However the number of bouts is significantly larger in males than in females ( $\mathrm{t}=\mathrm{I} .949 ; .05>\mathrm{P}>. \mathrm{OI})$. Rather than the expected differences, it appears that male sessions of cleaning are of equal length and more frequent than those of females.

At times of observations some individuals were pharate, some vials contained exuviae and others eggs. These allowed the animals to be subdivided into groups corresponding approximately to position in instar. Among the males only two ecdysed within the 24 hour isolation period, a sample too small to be meaningful. However among the females, the categories were sufficiently large to permit evaluation.

Table 2 gives the data for females of different types. Of the four pharate females, none exhibited any cleaning behavior. Comparison of recently ecdysed females and females with eggs to remaining females revealed no significant differences in bout length. In contrast, comparisons of cleaning frequency among these females showed that females with eggs clean significantly more often $(\mathrm{t}=2.488 ; 25 \mathrm{df} ; \mathrm{P} \quad$.OI $)$ than other females.

\section{Discussion}

As Simon (196I) has noted, the antennae, the location of important sensory receptors, are cleaned most often. There is possibly a positive correlation between frequency of cleaning and the required sensitivity of receptors. In pharate females the old receptors have presumably lost their nervous connections, so that there is no adaptive advantage in cleaning them. In contrast, females that have recently deposited eggs are sensitive to the required stalked spermatophores on the substrate. If this species has alternate reproductive and non- 
Table 2. Characteristics of cleaning bouts by females of various types.

\begin{tabular}{|c|c|c|c|c|c|c|}
\hline & & $\begin{array}{l}\text { aber } \\
\text { /an }\end{array}$ & & & $\begin{array}{l}\text { ngth } \\
\text { (in }\end{array}$ & \\
\hline & $\vec{x}$ & $\mathbf{n}$ & SD & $\bar{x}$ & $\mathrm{n}$ & SD \\
\hline Pharate females & 0 & 4 & 0 & - & 一 & - \\
\hline $\begin{array}{l}\text { Recently ecdysed } \\
\text { females }\end{array}$ & 1.63 & 19 & 1.34 & 22.4 & 31 & 29.0 \\
\hline Females with eggs & 2.1 & 9 & 1.05 & 20.8 & 19 & 28.9 \\
\hline Other females & 1.05 & 18 & 1.00 & 29.1 & 19 & 31.7 \\
\hline
\end{tabular}

reproductive instars with oviposition confined to early in the reproductive instar as Sinella curviseta (Waldorf, 1971), newly ecdysed females are possibly a mixture of two types: sensitive ones early in the reproductive interval and indifferent, or less sensitive ones, early in the nonreproductive instar. Although the distribution of numbers of cleaning bouts per female is not bimodal, the mean of this category is 1.63 , approximately the average ( 1.57 ) of the sensitive group with eggs and the remaining females. Note also that the variance of the number of bouts of recently ecdysed females is 1.796 and that of females with eggs and remaining females are I.IO2 and .998 respectively.

Considering males, Mayer (1957) has reported that males of Sminthurides aquaticus Bourlet clean more frequently when clasping the antennae of females than when alone. This is consistent with the hypothesis that these males are highly sensitive to olfactory stimuli.

The data indicate that males engage in more total cleaning than females. My recent studies of Sinella curviseta (Waldorf, in manuscript) demonstrate that females of this species produce a sex pheromone. This stimulates spermatophore deposition by males in the reproductive instar. Of the males in the present study 48 of 50 were in the reproductive instar at observation time. By frequent cleaning, these maintain their sensitivity to olfactory stimuli including possible pheromones.

\section{Literature Cited}

MAYER, H.

1957. Zur Biologie und Ethologie einheimischer Collembolen. Zool. Jahrb. abt. Syst. Okol. Geogr. Tiere 85: 501-570. 
Simon, H. R.

1961. Beobachtungen zum Verhalten arthropleoner Collembolen (Apterygota). Deutsch Entomolog. Z., N. F. $8: 216-221$.

1963. Zum Putzverhalten arthropleoner Collembolen (Ins,, Apterygota). Entomolog. Z., 73 : 221-228.

WALDORF, E. S.

1971. The reproductive biology of Sinella curviseta (Collembola: Entomobryidae) in laboratory culture. Rev. Ecol. Biol. Sol 8: 451-463.

Centennial of Entomology. Cornell University has announced a Centennial of Entomology, celebrating John Henry Comstock's graduation and the founding of studies in entomology at the University. A symposium on Insects, Science and Society will be held on October I4 and I5, I974. The speakers at the symposium will be as follows:

Howard E. Evans, Colorado State University: The Comstock Heritage.

John J. McKelvey, Jr., The Rockefeller Foundation: Insects and Human Welfare.

Edward O. Wilson, Harvard University: Insect and Human Societies.

John S. Kennedy, Imperial College Field Station, Ascot, England: Insect Dispersal.

Richard D. Alexander, University of Michigan: Insect Communication - Acoustical.

Wendell L. Roelofs, New York State Agricultural Experiment Station, Geneva: Insect Communication - Chemical.

Mano D. Pathak, International Rice Research Institute, Philippines: Patterns of Interaction between Plants and Insects.

T. R. E. Southwood, Imperial College Field Station, Ascot, England: The Dynamics of Insect Populations.

Powers Messenger, University of California, Berkeley: Parasitoids, Predators and Population Dynamics.

Waldemar Klassen, U.S.D.A., ARS-Plant Industry Station, Maryland: Pest Management-Organization and Resources.

L. Dale Newsom, Louisiana State University: Pest Management - Concept to Practice.

Further information can be obtained from the Chairman, Department of Entomology, Cornell University, Ithaca, New York 14850. 

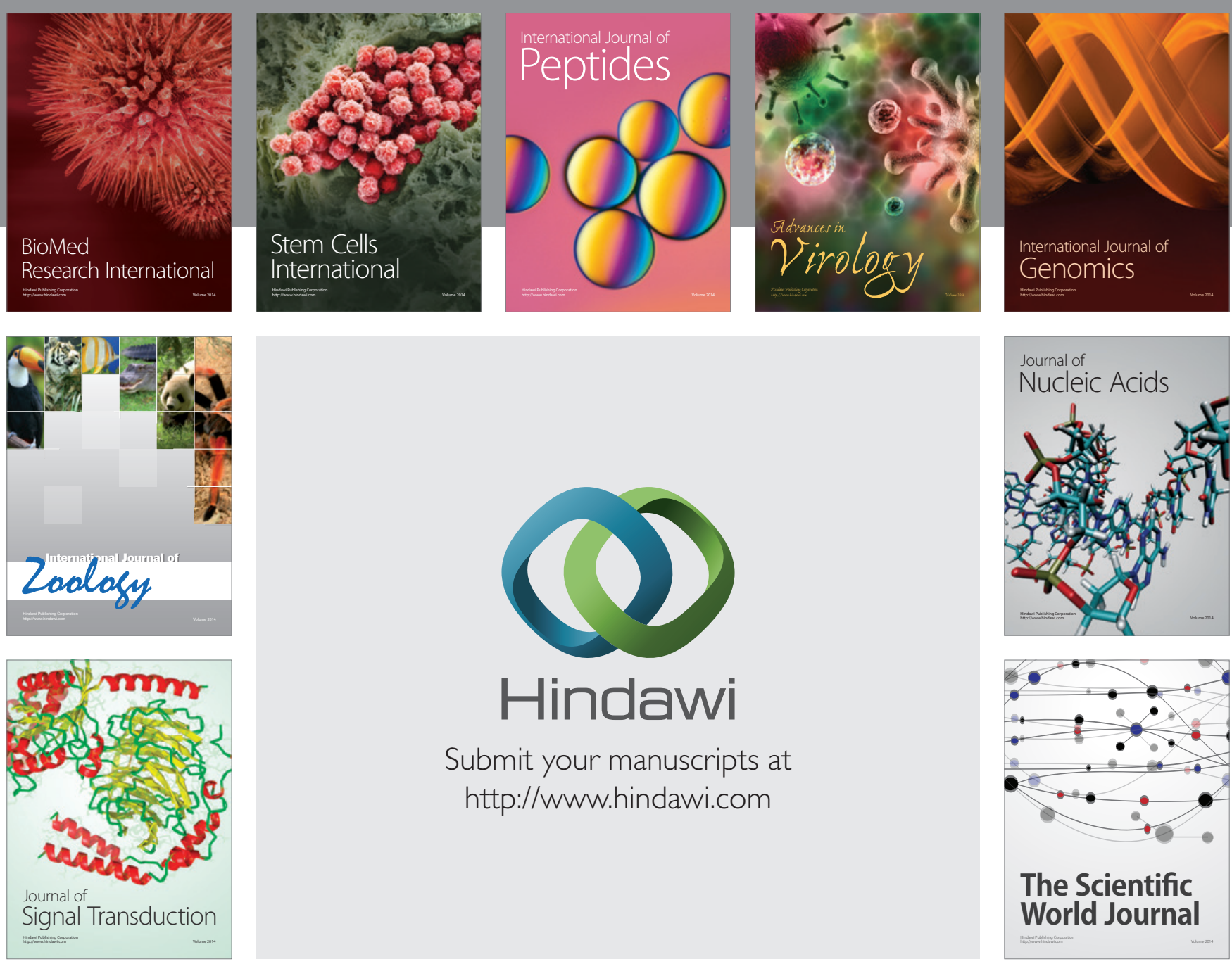

Submit your manuscripts at

http://www.hindawi.com
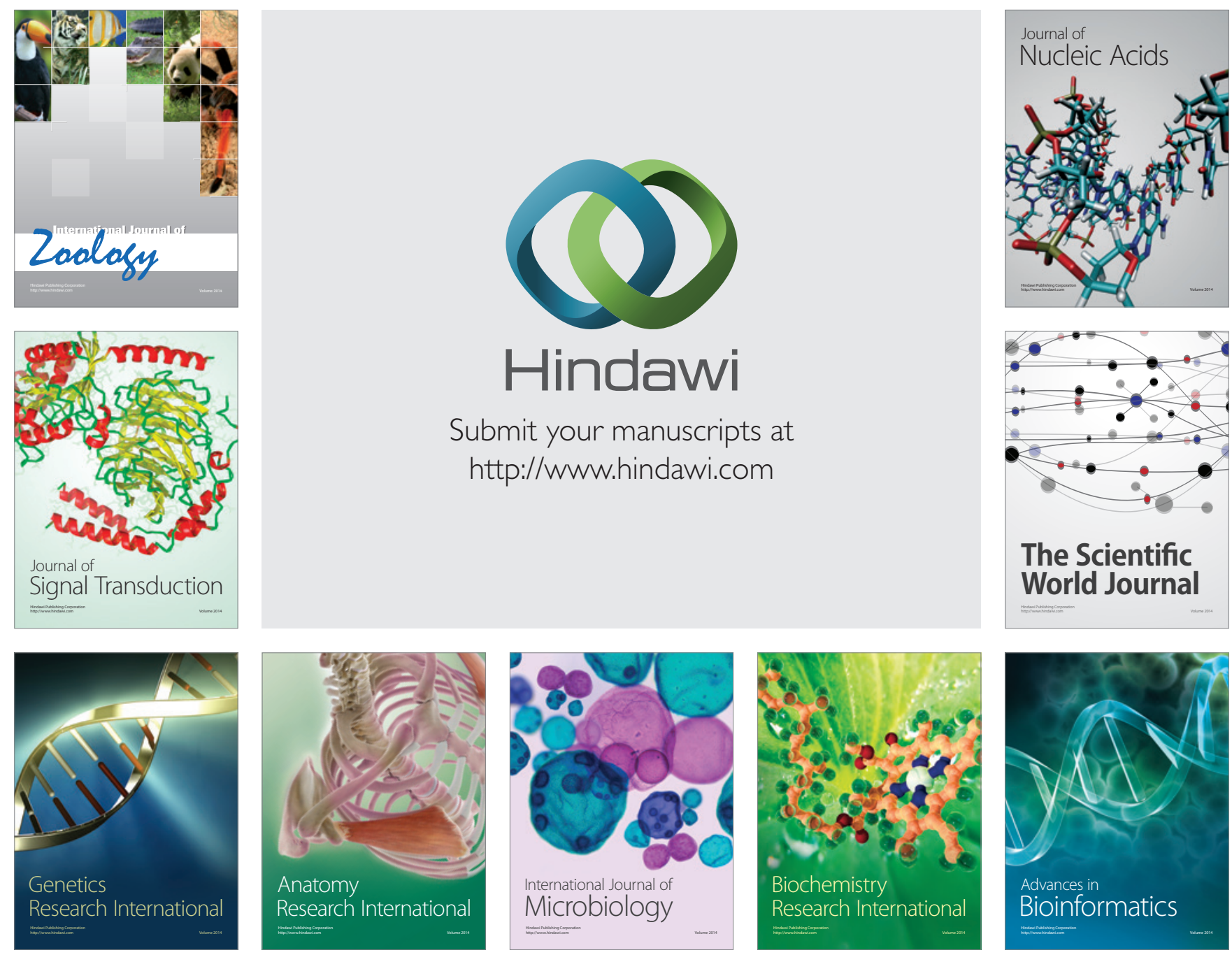

The Scientific World Journal
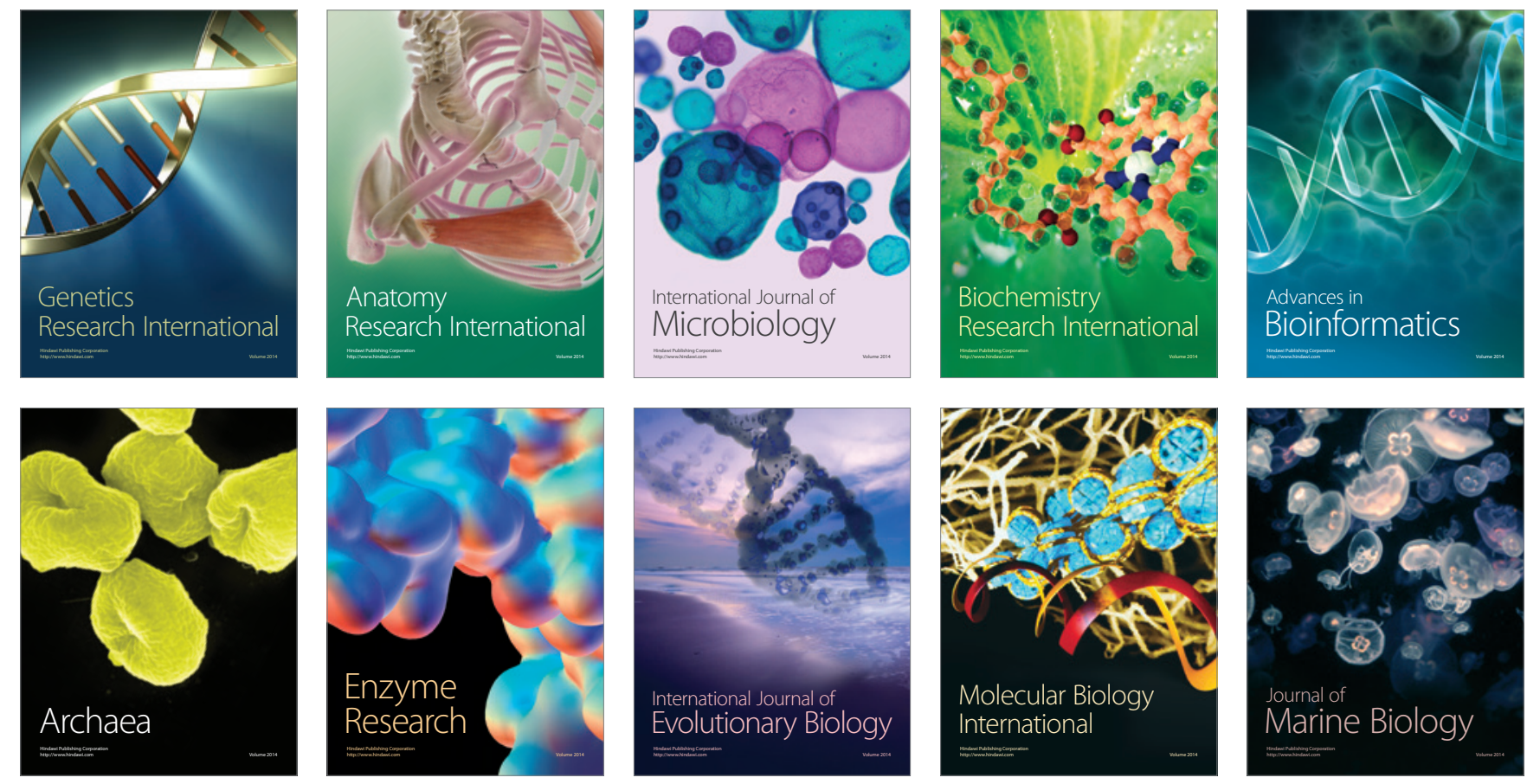